\title{
Prospects for Vietnam's Economy in 2013
}

\author{
TRÀ̀ HOÀNG NGÂN \\ Associate Professor, Doctor of Philosophy, University of Economics HCMC \\ Email: ngannh@ueh.edu.vn
}

\begin{abstract}
In 2012, Vietnam's economy faced great challenges. The world economy experienced more difficulties and complicated upheavals. International trade fell drastically while global growth rate was lower than predicted target, which affected badly the Vietnamese economy because of its full integration into the world economy and large openness. In this context, principal targets set for 2013 are macroeconomic stability, lower inflation rate, higher growth rate, three strategic breakthroughs associated with restructuring of the economy, and a new economic growth model. This paper analyzes obstacles to Vietnam's economic growth, and offers short-term solutions to bottlenecks and long-term ones to the economic restructuring.
\end{abstract}

Keywords: socioeconomic development, directions for 2013, world economy, Vietnam's economy, short-term solutions, long-term solutions. 


\section{VIETNAM'S ECONOMY IN 2012}

This is the fifth rough year of the world economy since crises in the real estate and finance markets in the US broke out in 2008. After the recovery of 5.1\% in 2010, the world economy kept falling to a double recession in two consecutive years. In 2011 and 2012, the growth rate just reached $3.8 \%$ and 3.3\% respectively. The Euro-zone, due to impacts of the public debt crisis, has impossibly weathered the recession; and the 2012 economic recession was $-0.4 \%$, the unemployment rate more than $11.7 \%$ with the highest unemployment rates falling to Spain (24.63\%) and Greece (24.4\%). In addition to economic recession, the world political security is extremely complicated by Sino-Japanese tensions in the East Sea, incidents in the Korean peninsula, particularly in the North Africa and Middle East, which has sharply affected the world socio-economy. Fluctuations in world oil price and the millions of dollars worth of arms races have reduced financial resources for economic recovery.

Vietnam became a WTO member in 2007 and its economic openness is quite high. In 2012 alone, the economic openness exceeded $160 \%$ (i.e. ratio of foreign trade value to GDP is US $\$ 227 \mathrm{bn} / \mathrm{US} \$ 136 \mathrm{bn}=166 \%$ ), and thus the world economic impacts on Vietnam are extremely profound.

Vietnam's economy in 2012 gained some achievements such as macroeconomic stability, low inflation rate in comparison with the 2011, a surplus in the payment balance (estimated around US\$8bn), foreign exchange reserves improved to stand 12 13 weeks of importation, stable exchange rates, export turnover rising by $16.6 \%$, the trade gap bridged (trade surplus in the first 11 months of 2012 was US\$14 million), stable attraction of FDI (around US\$10bn realized in 11 months), good disbursement of ODA (more than US\$3.6bn in 11 months), VND140,200-billion overspend as approved by Vietnam's National Assembly which equals $4.8 \%$ of GDP, public investment tightened, and public debts pegged at $55.4 \%$ of GDP.

Besides achievements, Vietnam's economy has still encountered plenty of difficulties and challenges.

\section{a. Economic Growth:}

The national economic growth rate in the first nine months of 2012 is $4.73 \%$, and that of the whole year is estimated to vary between $5.0 \%$ and $5.2 \%$. This is also the lowest growth rate in the past 13 years and even below the rate of $5.32 \%$ during the 2009 economic recession, and is also the second recessionary year in the row. 
Yet such the recession can be explained by the fact that Vietnam has been restructuring its economy and cut off public investments to settle economic defects (i.e. inflation, trade gap, budget overspend, etc.). If the recession gets deeper, it can impinge on the employment, social welfare and macroeconomic stability.

\section{b. Inflation Rate:}

According to the ADB Outlook 2012 Update, the 2012 inflation rate is approximately $8 \%$ which is lower than the $18.13 \%$ in 2011 and remains higher than those of many Southeast Asian countries such as Thailand (3\%), Malaysia (1.9\%), and Philippines (3.5\%). Besides the effective price management of the government, the 2012 inflation rate lower than that in 2011 is also due to the decline in aggregate demand, purchasing power and investment, and a relative stability of rice and foodstuff prices. Until November 2012, price index of rice-foodstuff dropped by $4.37 \%$ compared to the same period last year. It is worth noting that rice and other basic foodstuffs and food services constitute a tremendous percentage (39.9\%) in the basket of goods used for calculating the CPI.

High inflation rate and upheavals are caused by the distribution channels, price management, price disclosures, non-invoiced transactions, inconsistent stats, etc. Additionally, the fact that CPI has thus far been employed as a crucial basis for adjustments in interest rate and monetary policies makes thing go from bad to worse.

\section{c. Interest Rate:}

Vietnam's high inflation rate has made its interest rate two to three times higher than those in other Southeast Asian countries which have been adopting low interest rates to stimulate economic growth, such as Thailand (3\%), Malaysia (3\%), and the Philippines (2.75\%). In the meantime, Vietnam's interest rate is $9 \%$ at present.

High interest rate and unusual upheavals in past years have sharply affected the competitiveness of Vietnam's enterprises and investment decisions, especially longterm investment ones. Moreover, unusually high interest rates do also affect consumer loans, making lots of agreements on buying houses on hire purchase unattainable merely because the interest rate is unaffordable.

\section{d. Vietnam's Enterprises:}

In Vietnam some 50,000 enterprises had to go out of business or declared bankrupt (in September 2012 alone, this number was over 40,000). In the first eight months of 
2012, there were more than 345,000 applications for unemployment insurance. The high ratio of bankruptcy in recent years is partly due to the world economic upheavals, weak forecast, volatile financial and monetary policies, herd behavior and investment in real estate, stock market, banking, etc.

\section{e. Gross Investment:}

The gross investment in 2012 accounts for around 29\% of GDP, a decline of 4\% in comparison with plan. Since 2000, the ratio of gross investment to GDP has continuously remained higher than $40 \%$ per annum. Public investment for development is about VND187,000bn from national budget in conformity with the plan and VND45,000bn is collected from governmental bonds. Foreign direct investment reaches VND183,000bn, higher than expected. The total private investment alone is VND310,000bn, meeting $70 \%$ of the planned target. Development investment is supposed to pave the way for the development and employment. The ICOR of Vietnam in the period $2007-2012$ is 6.4 on average, thus the growth rate will be $5 \%$ if the gross investment in 2012 is merely around 29\% of GDP. How does private investment fail to attain the planned target? Is it due to the fact that many of private enterprises go broke and cannot access sources of capital, or that the interest rate exceeds the profitability of a project? It is possible that they are not financially competent yet are awaiting a better investment opportunity and a brighter macroeconomic situation. The low ratio of outstanding debts in 2012 reflects a decline in private investment. Outstanding debts in the whole economy (including corporate bond investments and investment authorization), as of Nov. 20, 2012, merely rise by $4.15 \%$ compared to late 2011 and are predicted to reach six to seven percent. This is the lowest credit growth rate in past decades. In the period $2000-2010$, the average credit growth rate was $30 \%$ p.a. While the money supply (M2) remains higher than $15 \%$, and bank deposits also rise more than $16 \%$ compared to the same period.

\section{f. Inventory:}

Inventories, especially those in manufacturing and construction industries are tremendous. They are maybe ordinary or luxury products, real estate, or construction materials. According to a GSO report, until Nov. 1, 2012, the amount of inventory in some fields has constantly risen, such as telecommunication equipment (425.1\%), fertilizer and nitrogen compounds (96.5\%), automobiles and motorbikes $(95 \%)$, beer (57.6\%), apparel (48.5\%), tobacco (45\%), battery (39.6\%), engine vehicles $(35.7 \%)$; 
cement (33\%), paper packages and cardboards $(26.3 \%)$, seafood $(24.9 \%)$, cosmetic and detergents $(21.7 \%)$, and so on.

\section{g. High Ratio of Bad Debts:}

According to an SBV report, bad debts ratio of banking institutions until June 2012 makes up $8.82 \%$ of the total outstanding debts, equaling VND250,000bn. Banking institutions have put VND75,000bn in the contingency reserve. Almost all bad debts are related to fluctuations in the real estate market, either directly or indirectly. While the real estate price has been dropping in comparison with that in 2007, the real estate market keeps being frozen, and thereby hampering banks from selling foreclosed realty. Depreciation and a freeze of real estates have made the bank's bad debts deteriorate, which sharply affects the implementation and regulation of macroeconomic policies, the security of banking system as well as depositors' trust in the national banking system.

The aforementioned setbacks are partly due to the world economic crisis, the European public debt crisis, socio-political volatility in North Africa and Middle East, tensions in the East Sea, which have adversely affected our economy. Besides, the poor governance, the lack of synchronous collaboration among related agencies, the superficial inspection of the operation of state-owned corporations, etc. also contribute to the setbacks. The competitiveness of enterprises and the whole economy is not much improved in the context of world economic integration. Forecasts are slow and cannot keep up with rapid changes in the world.

\section{PROSPECTS FOR VIETNAM'S ECONOMY IN 2013}

In 2013, the Year of Snake, Vietnam's economy keeps being challenged in early months due to the fact that they must tackle difficulties such as inventories, bad debts, and a stagnant realty market, etc. Particularly, the world economy has not fully regained its health. Yet international financial organizations predict a brighter future for Vietnam's economy in 2013 than the previous year. Specifically, World Bank and ADB predict a growth rate of 5.9\% while the IMF foresees a growth rate of $5.7 \%$. The fourth session of Vietnam's National Assembly XIII determines targets for the Vietnam's economy in 2013 as follows: a growth rate of $5.5 \%$, a rise of $10 \%$ in the export turnover, the trade gap pegged at $8 \%$, budget overspend not exceeding $4.8 \%$, a rise of some $8 \%$ in CPI, the gross investment equaling $30 \%$ of GDP, employment for 1.6 million workers, urban unemployment ratio lower than $4 \%$, and so on. 
The stated predictions and targets are absolutely viable due to tremendous economic potentials of Vietnam such as abundant human resources with 88 million people. However, some fields and industries have not operated effectively such as tourism, agriculture, and marine economy; public assets are utilized extravagantly; investments are not productive; major construction works are defective, etc. Therefore, it is necessary to formulate appropriate policies and invest wisely and effectively in keynote industries to facilitate the sustainable development of Vietnam's economy.

The government should work out short-term solutions to deal with bottlenecks to facilitate the production and distribution, dispose of inventory as well as bad debts, and create jobs. Long-term solutions should be continuously undertaken to restructure the economy in the direction of effective utilization of social resources, boosting the labor productivity, facilitating the sustainable economic development, and improving the living standards.

\section{a. Short-Terms Solutions:}

It is necessary to dispose of bad debts and clarify responsibilities of persons and organizations who cause damage when settling bad debts. Administrative procedures related to foreclosure and sale of foreclosed assets must be reformed. The SBV should collaborate with related agencies to formulate an instrument to dispose of mortgages and facilitate the settlement of bad debts. When dealing with bad debts, commercial banks (lenders) and enterprises (borrowers) will primarily hold responsible for bad debts they generated, and thereby making the restructuring of commercial banks and state-owned enterprises more rapid and transparent. In the first eight months of 2012, banking institutions often utilized VND8,000bn from contingency reserves to make up for bad debts; and this is not a tremendous figure. In addition to commercial banks and enterprises, bad debts are also related to many ministries and local authorities; and thus the government should establish an inter-ministerial inspectorate and an assets and liabilities management company to deal with bad debts. The settlement of bad debts should be monitored by the National Assembly Economic Committee to assure the transparency.

The implementation of domestic and foreign trade can be supported by preferential treatments such as transport fees to study target markets, establishment of local distribution networks, and bringing locally-made products to remote areas, etc. It is needed to organize campaigns to encourage Vietnamese to use Vietnamese products, 
honor high-quality products, boycott poisonous and low-quality ones; to collaborate with agencies to strictly control import and export along the border; to fight against contraband or counterfeit goods which can adversely impinge on consumers and honest manufacturers in Vietnam.

With regard to the real estate market, it is needed to resort to synchronous solutions such as reducing the supply of real estate which is hardly consumed, lowering their prices to stimulate the market demand, subdividing big lots, adopting preferential lending rate for people in need, exempting VAT for initial or short-term transactions, reforming administrative procedures related to real estate, changing the function of a property to match the real need (dormitory, schools, hospitals, apartments for lowincome workers, houses for rent, etc.), enabling expatriate Vietnamese and foreigners to buy realty. Besides, monitoring, inspecting and revoking suspended zoning projects and unnecessary ones or those which are not useful for national defense must be strictly done. Once zoning projects are revoked, local people are allowed to carry out civil constructions, and thereby the inventory of building materials can be settled. Once vacant lands are available, hospitals, schools, dormitories and social houses can be developed to deal with the current imbalance and enhance the training of well-qualified human resources.

Leading provinces can be enabled to issue municipal and revenue bonds to implement crucial and far-reaching projects. Yet, it is also needed to monitor public investment projects so as to avoid extravagance, suspension, or being fallen behind the schedule.

The government should help farming households, and small and medium-sized enterprises in terms of credit accessibility, taxes, fees, interest rates, bank rates, and administrative procedures, etc. Funds for development and credit guarantee of small and medium-sized enterprise should be enhanced with more favorable guarantee terms and conditions. Enterprises should restructure their business in the direction of investing in keynote fields, ensuring the transparent financial disclosures, and soon go public to avoid depending too heavily on bank loans which can be exacerbated if commercial banks restrict lending due to the state bank's tight monetary policy.

The ceiling rate should be regulated with the reference to the basic inflation rate which is sharply affected by non-monetary factors or force majeure such as natural disasters, plague that make foodstuff price rise, or complicated sociopolitical situation 
in North Africa and Middle East that make the oil dearer, and so on. Hence, it is impossible to manipulate the interest rate as per the CPI yet as per the basic inflation rate (i.e. the comprehensive inflation rate excluding fluctuations in oil and foodstuff price).

Inflation can peak again in 2013, so the government should quickly implement the Pricing Law approved by the Vietnam's National Assembly XIII on June 20, 2012 and validated as of Jan. 1, 2013 to manipulate prices and curb inflation. While employees' income is still low, the control over inflation is really significant. Accordingly, governmental agencies should study and inspect pricing mechanism as for products and services over which the government has the full authority to price, or those whose prices often fluctuate.

It is necessary to organize distribution channels, silos and inventory of basic raw materials and necessities such as gasoline, rice and other foodstuffs to stabilize prices and curb inflation.

Besides, fiscal and monetary policies should aim to weather the economic recession and curb unusual rise in the interest rate. In 2013, the SBV must take the keynote role in the fight against economic recession. The Ministry of Finance and the Ministry of Industries and Trade must collaborate with each other and related agencies to curb inflation and manipulate trade gap. The Ministry of Finance and state budget-financed organizations should be thrifty, balance incomes and spending so as to balance the state budget and keep the budget overspend smaller than VND162,000bn (or 4.8\% of GDP).

\section{b. Long-Term Solutions:}

It is an urgent need for Vietnam to restructure its economy. Hence, a comprehensive scenario must be specifically formulated to clarify the duty of each organization involved in the restructuring with a view to utilizing effectively social resources, boosting labor productivity, assuring the sustainable development and better living standards.

The restructuring of banking institutions must observe the Prime Minister's Decision 254/QĐ-TTg dated March 1, 2012. Besides, it is needed to inspect and monitor the operation of banks and seriously penalize any breach of law. Together with settlement of bad debts in 2013, the government can nationalize or merge banks with bad performance or shortage of chartered capital. 
When restructuring state-owned enterprises, especially state-owned corporations, it is necessary to streamline the business administration system and enhance the business performance. The government should direct ministries and agencies to reevaluate the operation of state-owned corporations and enterprises; and implement the project on restructuring state-owned corporations in the period $2011-2015$ which was approved by the Prime Minister via the Decision 929/QĐ-TTg dated July 17, 2012. Each stateowned corporation and group must work out a specific restructuring plan which shall be approved and followed. Accordingly, it is necessary to: (1) expedite the privatization (yet the government holds $100 \%$ the chartered capital in fields of national defense and security, and in socio-economically significant enterprises); (2) reorganize, liquidate or shut down enterprises with bad performance, inability to make profit, and insolvency; (3) avoid investing in fields unrelated to the government's role and function; and (4) clarify the government's roles of inspector, governor, and business administrator. The Prime Minster's Decree 99/2012/NĐ-CP dated Nov. 15, 2012 concerning classification of rights and obligations attached to the leadership of state-owned enterprises and investments in such kind of enterprise must be implemented seriously due to the fact that it plays an important role in management and inspection of state-owned enterprises. Accordingly, related ministries and agencies should work out specific directives to bring this Decree to life as soon as possible.

The restructuring of the national economy must observe principles of delegation of authority over investment management. When allocating investment budget, the government should attend to the national competitive advantages, especially those in tourism, agriculture and marine economy, which have thus far been ignored.

While there are around $68 \%$ of population in rural areas and $48 \%$ depending on agriculture, the gross investment in agriculture continuously drops from $13.6 \%$ in the period $1996-2000$ to $6.4 \%$ in $2006-2010$ and even around $6.2 \%$ in 2011 . Just in 2011 , the agriculture contributed $22 \%$ to the GDP. Thus, if the agriculture is properly invested in combination with investment in the industrialization, technological advances, seedlings, traffic network, processing machinery, etc., Vietnam's agriculture will develop rapidly and fortify its position in the world economy. Consequently, the living standards of Vietnamese farmers will definitely be enhanced. Therefore, the government should adopt agriculture-incentive policies such as preferential interest rate, exemption or reduction in taxes, agricultural insurance policies, international trade supports, and silos, etc. 
Development of Vietnam's tourism has not matched its potentials. Therefore, it is necessary to work out appropriate policies to improve the national tourism, attract foreign tourists and retain domestic ones.

Marine economy has a tremendous potential for development. Yet, Vietnam's port services are restricted, and the fishing boats are quite simple and unproductive. Therefore, the government should invest in modern fishing boats, which are socioeconomically significant and help protect the national coastline.

The stated solutions, if undertaken synchronously and effectively, Vietnam's economy in 2012 is expected to take a long step

\section{References}

ADB (2012), Asia Bond Monitor (September 2012) and Outlook 2012 Update (October 2012)

Government of Vietnam (2012), "Báo cáo của Chính phủ về kinh tế - xã hội năm 2012 và phương hướng năm 2013” (Report on socio-economic development in 2012 directions for 2013).

GSO (2012), "Báo cáo kinh tế - xã hội từ tháng 01 đến tháng 11 năm 2012" (Socioeconomic report for 11 months of 2012).

IMF Report for October 2012 